\title{
Need for Social Approval and Happiness in College Students: The Mediation Role of Social Anxiety ${ }^{*}$
}

\author{
Burcu Karaşar*, Kemal Baytemir \\ Department of Psychological Counseling and Guidance, Amasya University, Amasya, Turkey
}

Copyright $\bigcirc 2018$ by authors, all rights reserved. Authors agree that this article remains permanently open access under the terms of the Creative Commons Attribution License 4.0 International License

\begin{abstract}
The reflection of the presence or absence of social relationships as a basic human need on the individual has been investigated in different ways. The purpose of the current study is to investigate the mediation role of social anxiety in the relationship between the need for social approval and happiness. A total of 285 students, of whom $212(74.4 \%)$ are females and $73(25.6 \%)$ are males, participated in the study. In the study, a Personal Information Form, the Social Anxiety Scale developed by Özbay and Palanc1 [1] the Need for Social Approval Scale developed by Karaşar and Ögülmüş [2] and the Oxford Happiness Scale adapted by Doğan and Sapmaz [3] were used to collect data. Whether the mediation role of social anxiety in the relationship between the need for social approval and happiness is statistically significant was investigated through the software program developed by Hayes [4,5], the approach based on the ordinary least square method and the bootstrap method. As a result of the study, it can be argued that social anxiety plays a mediation role in the relationship between the need for social approval and happiness. Moreover, it was found that the whole model was at a significant level and happiness explains $27 \%$ of the total variance. The findings of the study were discussed in such a way as to shed light on further research and practitioners.
\end{abstract}

Keywords Social Anxiety, Need for Social Approval, Happiness, University Students

\section{Introduction}

People have tried to understand and pursued happiness throughout the history. According to Frey and Stutzer [6] each person wants to be happy in his/her life. It has been stated that the greatest objective people want to achieve in their lives is happiness. What happiness is and what makes people happy has been a subject of greater interest since 2000 s with the development of positive psychology. Happiness is defined through different concepts such as subjective well-being, psychological well-being and mental well-being. Although there is no consensus among the researchers in this area to define positive mental health, it is stated that the concept of subjective well-being is used more widely in defining happiness [7]. In this regard, happiness is defined as the abundance of positive feelings, scarcity of negative feelings and satisfaction in life $[8,9]$. When happiness is defined as psychological well-being, it is seen as self-actualization, establishment of positive relationships and pursuit of meaning and purpose in life $[10,11]$. In describing happiness, mental well-being is seen as an upper roof covering subjective well-being and psychological well-being [12].

What makes people happy is an issue of great diversity. Some of the variables affecting happiness have been reported to be; aside from age, gender and income level, life purposes [13, 14], faith [15, 16], emotional intelligence [17], self-awareness [18, 19], hope [20, 21], resilience [22, 23].

The reflection of the presence or absence of social relationships as a basic human need on the individual has been investigated in different ways. Being successful in social relations; that is, establishing effective and appropriate social relations, is also seen as an important source of happiness. The research has revealed that interpersonal competence [24], social skills [25, 26], peer relations [27], social skills and friendship [28] are significantly correlated with happiness. Diener and Seligman [29] emphasized the importance of social bonds for happiness. In their study, it was found that the happiest people have good social bonds and spend most of their time socializing. It was also found that such people spend little time on their own. At the same time, it was concluded that the happiest people have good social bonds and are extravert. When social bonds are threatened or broken, negative feelings can surge [30]. People who do not establish effective and appropriate relationships in their social lives are defined as socially anxious and shy [31]. Thus, social anxiety can be considered a state of not possessing social skills and interpersonal competence. Aronson, Wilson and Akert [32] have emphasized that 
social interactions with other people have an impact on the individual's feeling good. People who are struggling to establish social ties with people around can experience difficulties in achieving the greatest objective of life; namely, happiness. Problems such as social anxiety disorder, which create difficulties especially in social relations, can cause unhappiness in individuals as an important factor. Kring, Johnson, Davison, and Neale [33] define social anxiety disorder as an irrational and persistent fear experienced in social settings. This problem emerging in the period of puberty can be obstructive especially in developing friendship relationships.

In case of social anxiety, individuals experience intense anxiety in social environments or in situations where they are expected to demonstrate performance. Socially anxious people can exhibit avoidance behaviors due to concerns that they may be exposed to situations in which they can be judged or embarrassed by other people [34]. Socially anxious individuals intensely focus on the impression they are creating on others and believe that others will have negative impressions about them. As they see themselves socially incompetent, they believe that they will attract attention in social environments, everybody will look at and criticize them [35]. Individuals experiencing social anxiety due to their conviction that other people will judge them negatively in social environments may also be of the opinion that they are bad at social skills. Due to this conviction, they can demonstrate apprehensive and avoidance behaviors in social environments. They can think that their behaviors in social environments will be improper and may be negatively judged by others [36].

Researchers have concluded that the happiness level of the individuals with higher social anxiety is greater than that of the individuals with lower social anxiety; thus, the individuals with higher social anxiety can be relatively unhappier. People with social anxiety disorder can face one or more psychological disorders during their lifetime [34]. There are various studies reporting a negative correlation between social anxiety and psychological well-being [37,38]. Demir and Kutlu [39]; in their study conducted on university students, found that social interaction anxiety negatively predicts happiness. They reported that with increasing social interaction anxiety, happiness decreases.

Social anxiety seems to be related to the need for social approval. The need for social approval, a concept related other's admiration [40] and to the concern of "What others say" [2], is believed to be associated with social anxiety. In case of social anxiety disorder, individuals are afraid of exhibiting bad performance in social environments. These people are hypersensitive to rejection and focus on others' opinions. They are very afraid of being negatively judged by others in social settings [41]. In socially anxious individuals, the desire to be approved by others and attract their attention can be seen intensely. People with social anxiety can avoid situations where they think they will not be socially approved because of their fear of humiliation and embarrassment [42]. Another argument about the need for social approval and social anxiety is that individuals feeling the need for social approval tend to experience social anxiety as they take great motivate to lea ve a positive impression [43]. Leary and Kowalski [44] also pointed out that individuals with high level of need for social approval experience more social anxiety when compared to individuals with low level of need for social approval.

As known, another variable related to the need for social approval is happiness. Karaşar [45] stresses that very high or low levels of need for social approval might lead to various problems in the social and emotional worlds of people. Baumeister and Leary [46] noted that unmet needs might cause medical, psychological, or behavioral pathology. Looking at the literature, there seems to be limited research on the need for social approval and happiness. In a study conducted by Karaşar and Ögülmüş [2] happiness was found to be negatively predicted by the need for social approval.

Given the delineations above, it is clear that one of the important sources of happiness is social relationships. The happiness of individuals who have difficulty in establishing social relations though they wish to do so or who take extra care and consideration of other people's opinions in social contexts may be affected from these. Therefore, it is thought to be important to understand the relation of those characteristics that undermine the social relations providing satisfaction for people with happiness. In this connection, the purpose of the current study is to determine the mediation role of social anxiety. Research conducted in Turkey on university students has revealed that frequency of experiencing social phobia and social anxiety is high among this population. İzgiç et al. [47] found that the age group in which social phobia is experienced most widely is 21-24. Tekin [48] carried out a study on university students and found that $48.8 \%$ of the students exhibit the syndromes of social anxiety disorder. In a study done by Gültekin and Dereboy [49] on university students, it was found that the annual prevalence of social phobia is $20.9 \%$ and the life-long prevalence of it is $21.7 \%$. These research findings show that social anxiety among university students is an important problem. Yet, when the literature was reviewed, no study was found exploring the mediation role of social anxiety in the relationship between the need for social approval and happiness. As social anxiety is closely associated with both the need for social approval and happiness, it can be anticipated to have a mediation role between these variables. Seen from this perspective, high level of need for social approval can be related to increasing number of social anxiety symptoms and decreasing happiness. The purpose of the current study is to test the mediation role of social anxiety in the relationship between the need for social approval and happiness. In line with this purpose, the following hypotheses have been developed. 
- Hypothesis 1. There is a direct negative correlation between the need for social approval and happiness.

- Hypothesis 2. There is a direct positive correlation between the need for social approval and social avoidance.

- Hypothesis 3. There is a positive correlation between the need for social approval and the fear of being criticized.

- Hypothesis 4. There is a direct positive correlation between the need for social approval and sense of worthlessness.

- Hypothesis 5. There is a direct negative correlation between social anxiety and happiness.

- Hypothesis 6. By increasing social anxiety, social approval negatively and indirectly correlates with happiness.

\section{Method}

\subsection{Research Model}

The current study employed the correlational research design. The correlational research aims to investigate the relationship between two or more variables without any intervention directed to influencing the relationship between these variables [50]. The causal relationships between the variables of the current study; the need for social approval (predictor variable), social anxiety (mediating variable) and happiness (criterion variable), were tested by using mediation analyses.

\subsection{Study Group}

The universe of the study is comprised of all the students attending a university in the Central Black Sea Region in Turkey. The sampling of the study; on the other hand, consists of the students of the education faculty in this university. A total of 285 students of whom 212 (74.4\%) are females and $73(25.6 \%)$ are males participated in the study. The mean age of the participants is $20.49, \mathrm{Ss}=2.09$. In the selection of the sampling, the convenient sampling method was used.

\subsection{Data Collection Tools}

Personal Information Form: It was developed by the research to collect information about the gender, age and grade level of the participants.

The Need for Social Approval Scale: The scale developed by Karaşar and Ögülmüş [2] to measure the need for approval is a five-point Likert scale consisted of three sub-dimensions of the need for social approval (sensitivity to others' judgments, leaving positive impression and social withdrawal). The scale is comprised of 25 items and high scores from the scale coincide with high needs for social approval. The scale items are scored between "Strongly Agree" and "Strongly Disagree". The internal consistency coefficient calculated for the whole scale was found to be .90 . The internal consistency coefficients calculated for the sub-dimensions of the Need for Social Approval Scale were found to be ranging between .80 and .83 . The convergent and discriminant validity was also tested. For this purpose "The Fear of Being Judged Negatively Scale Short Form" was used. The correlation between these two scales was found to be .79 . Pretest-posttest reliability of the scale was found to be .90 . The internal consistency coefficients of the three sub-dimensions of the scale are as follows: sensitivity to others' judgments .83 , social withdrawal .80 , leaving positive impressions .80 and for the whole scale it was found to be .90 . The construct validity of the scale was tested with CFA. As a result of CFA performed on the two groups, the fit indices were found to be at good levels. While the fit indices for the first group are; $\mathrm{x}^{2} / \mathrm{sd}=2.11$, $\mathrm{RMSEA}=.06, \mathrm{NNFI}=.94, \mathrm{CFI}=.95, \mathrm{RMR}=.06, \mathrm{NFI}=.90$, $\mathrm{IF}=.95$, they are as follows for the second group; $\mathrm{x}^{2} / \mathrm{sd}=$ 2.23, $\mathrm{RMSEA}=.06, \mathrm{NNFI}=.95, \mathrm{CFI}=.96, \mathrm{RMR}=.06$, $\mathrm{NFI}=.92, \mathrm{IF} \mathrm{I}=.96$.

The Social Anxiety Scale: “The Social Anxiety scale developed by Özbay and Palancı [1] was developed to determine university students' social anxiety-related problems. The scale developed in such a way as to measure university students' skills and anxiety related to their social situations is a Likert type scale comprised of 30 items. The response options for the scale items are scored between 0 and 4 . The scale has three sub-dimensions that are social avoidance, fear of being criticized and personal worthlessness. High scores taken from the scale indicate an increasing social anxiety.

The total variance explained by the sub-dimensions of the scale (social avoidance, fear of being criticized and personal worthlessness) was found to be $32.9 \%$. In order to test the criterion validity of the scale, its correlation with the social introversion sub-dimension of MMPI was calculated and it was found to be .43. The results of the criterion validity analysis conducted with the interpersonal sensitivity, anxiety, phobic anxiety and depression sub-dimensions of the SCL-90 scale revealed that its correlation with interpersonal sensitivity is .51 , with anxiety .25 , with phobic anxiety .36 and with depression .40. The Cronbach Alpha value of the Social Anxiety Scale is .89.

The Oxford Happiness Scale: "The Oxford Happiness Scale" developed by Hills and Argyle [51] was adapted to Turkish by Doğan and Sapmaz [3]. The scale consists of 28 items. The scale is a unidimensional and 6-point Likert scale. The response options of the scale items range between "Strongly Disagree" to "Strongly Agree". The total explained variance of the scale is $29.84 \%$. The factor loadings of the scale items are between .32 and .77 . Due to 
its low factor loading, one item in the 29-item original scale was excluded from the analyses. The results of the exploratory factor analysis showed that this scale is a construct made up of a single dimension. The results of the confirmatory factor analysis applied to the scale also confirmed the unidimensional structure of the scale.

Cronbach Alpha coefficient calculated for the reliability of the scale was found to be .91 . As a result of the split-half analysis, the reliability coefficient of the scale was found to be .86 . In addition to this, the composite reliability of the scale was also tested and it was found to be .91 .

In order to test the criterion validity of the scale, the Life Satisfaction Scale, the Scale of Positive Feelings, the Scale of Negative Feelings, the Life Disposition Test and the Subjective Happiness Scale were used. The correlation of the Oxford Happiness Scale with the Scale of Life Satisfaction was found to be .69 , with the Subjective Happiness Scale .72, with the Scale of Positive Feelings .64, with the Scale of Negative Feelings -.60 and with the Life Disposition Test (optimism) .72. As a result of the confirmatory factor analysis of the scale, the goodness-of-fit indices were found to be as follows: $\mathrm{x}^{2} / \mathrm{sd}=$ 4.2, RMSEA $=.08, \mathrm{NNFI}=.98, \mathrm{CFI}=.94, \mathrm{RMR}=.06$, $\mathrm{NFI}=.92, \mathrm{IFI}=.94$. Thus, it was concluded that the scale is a valid and reliable scale to measure university students' happiness.

\subsection{Procedure}

In the current study, the Personal Information Form, The Need for Social Approval Scale, The Social Anxiety Scale and The Oxford Happiness Scale were administered to the pre-service teachers voluntarily participating in the study. It took nearly 10-15 minutes for the pre-service teachers to complete the scales. In the analysis of the collected data, descriptive statistics and Pearson correlation coefficient were used. Whether the mediation effects of the model tested are statistically significant was tested through the software program developed by Hayes [4,5], the approach based on the ordinary least squares method and the bootstrap method. Bootstrap analyses were performed by using "Multiple Mediation Model 4" in PROCESS Macro. Whether the mediation role of the mediator variable is statistically significant was examined on 5000 bootstrap samples. The independent variable of the study is the need for social approval, the mediator variable is social anxiety and the criterion variable is happiness. The significance level was set to be .01. In the analysis of the data, IBM SPSS 22.0 program package was used.

\section{Findings}

In the current study, Pearson correlation analysis was used to determine the correlations between the variables. The descriptive statistics and correlation results related to the variables of the need for social approval, social avoidance, fear of being criticized, sense of worthlessness and happiness are given in Table 1.

As can be seen from the correlation values given in Table 1, the need of social approval is significantly and positively correlated with the social avoidance $(.57 p<.01)$, the fear of being criticized $(.67 p<.01)$ and the sense of worthlessness $(.55 p<.01)$ sub-dimensions of social anxiety, yet, significantly and negatively correlated with happiness $-.14(p<.05)$. Happiness was found to be significantly and negatively correlated with the social avoidance (-.41 $p<.01)$, the fear of being criticized $(-.29 p<.01)$ and the sense of worthlessness $(-.46 p<.01)$ sub-dimensions of social anxiety. As theoretically anticipated, the need for social approval was found to be positively and significantly correlated with social anxiety and negatively and significantly correlated with happiness. The sub-dimensions of social anxiety were also found to be negatively and significantly correlated with happiness.

The findings obtained from the multiple mediation analysis conducted in the current study aiming to investigate the mediation role of social anxiety in the relationship between the need for social approval and happiness are presented in Figure 1.

Table 1. Descriptive Statistics and Pearson Correlation Coefficient Values related to the Variables of the Study

\begin{tabular}{|ccccccc|}
\hline Variables & $\bar{X}$ & Ss & $\mathbf{1}$ & $\mathbf{2}$ & $\mathbf{3}$ & $\mathbf{4}$ \\
\hline 1.The need for social approval & 69.57 & 14.81 & --- & & & \\
\hline 2.Social avoidance & 15.97 & 8.94 & $.57^{* *}$ & -- & & \\
\hline 3.Fear of being criticized & 14.73 & 7.16 & $.67^{* *}$ & $.78^{* *}$ & -- & \\
\hline 4.Sense of worthlessness & 8.74 & 5.32 & $.55^{* *}$ & $.74^{* *}$ & $.79^{* *}$ & -- \\
\hline 5. Happiness & 116.98 & 21.15 & $-.14^{*}$ & $-.41^{* *}$ & $-.29^{* *}$ & $-.46^{* *}$ \\
\hline $\mathrm{N}=285, * * p<.01, * * p<.05$ & & & & & & - \\
\hline
\end{tabular}




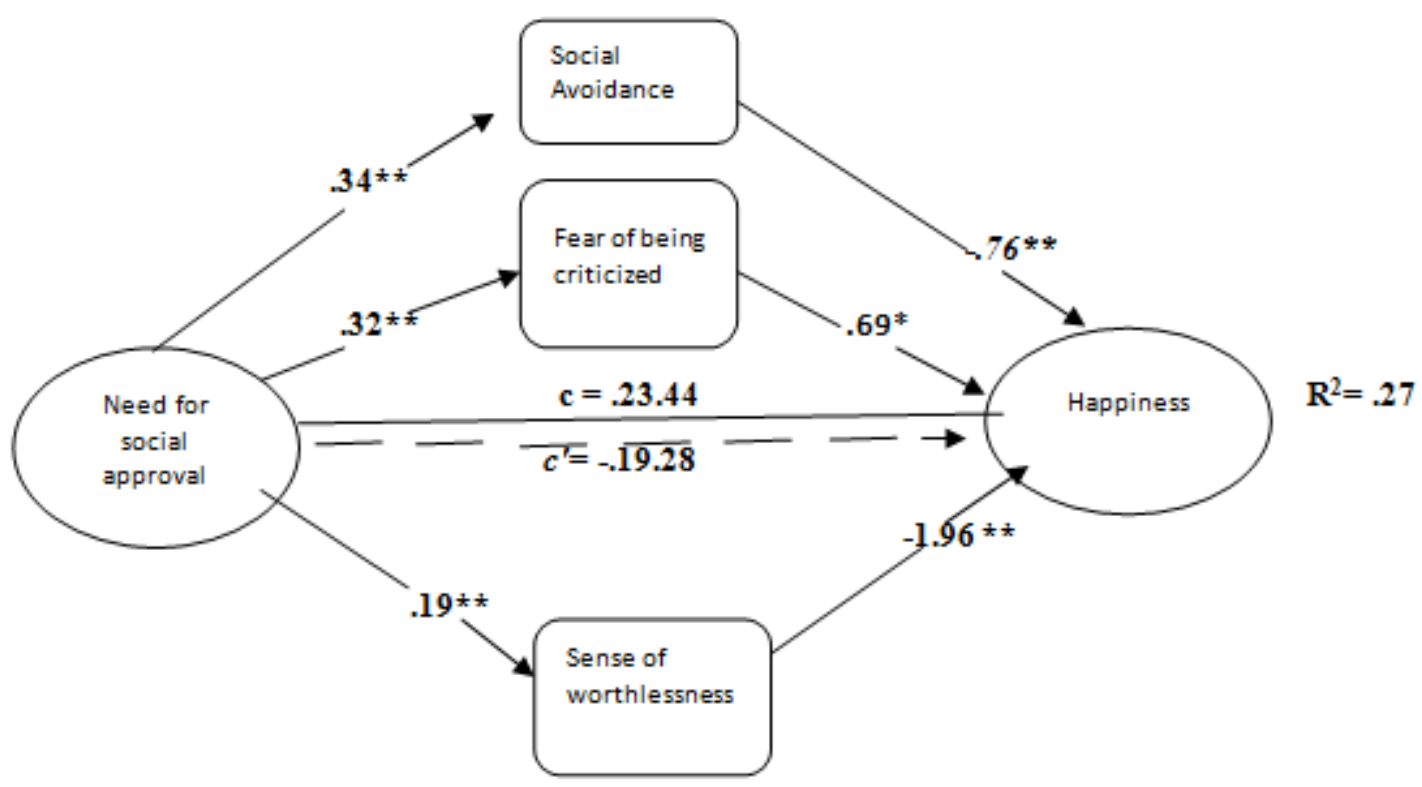

Figure 1. The mediation role of social anxiety in the relationship between the need for social approval and happiness and the standardized beta values $* p<.05, * * p<.01$

As can be seen in Figure 1, the total effect of the need for social approval on happiness is significant $(\mathrm{c}=.23 .44$, $\mathrm{SH}=.09, \mathrm{t}=2.38, p<.05$ ) (Step 1). Moreover, the direct effect of the need for social approval on the social avoidance sub-dimension $(\mathrm{B}=.34, \mathrm{SH}=.03, \mathrm{t}=11.53$, $p<.01)$, the fear of being criticized sub-dimension $(\mathrm{B}=.32$, $\mathrm{SH}=.02, \mathrm{t}=15.07, p<.01)$ and the sense of worthlessness sub-dimension $(\mathrm{B}=.20, \mathrm{SH}=.02, \mathrm{t}=11.19, p<.01)$ of social anxiety, which is the mediator variable, is significant (Step 2). The direct effect of the social avoidance sub-dimension $(\mathrm{B}=-.76, \mathrm{SH}=.20, \mathrm{t}=-3.73, p<.01)$, the fear of being criticized sub-dimension $(\mathrm{B}=.69, \mathrm{SH}=.30, \mathrm{t}=2.32, p<.05)$, the sense of worthlessness sub-dimension $(\mathrm{B}=-1.97$, $\mathrm{SH}=.35, \mathrm{t}=-5.61, p<.01)$ of social anxiety on happiness is significant (Step 3). When the need of social approval and the sub-dimensions (social avoidance, fear of being criticized and sense of worthlessness) of social anxiety were simultaneously included in the equation (Step 4), the correlation between the need for social approval and happiness decreased in terms of direct effect; yet, the significance level managed to remain at the same level $\left(c^{\prime}=\right.$ $-.19, \mathrm{SH}=.08, \mathrm{t}=2.29, p<.05)$. Thus, it can be maintained that social anxiety plays a mediation role between the need for social approval and happiness. Moreover, it is seen that the whole model is at a significant level $\left(\mathrm{F}_{(4-280)}=25.58\right.$, $p<.01$ ) and happiness explains $27 \%$ of the total variance.

Values related to effects between the variables of the model tested in the current study are given in Table 2 .

Whether the indirect effects in the model tested in the current study are statistically significant was tested on 5000 bootstrap sample. The estimates were evaluated in the $95 \%$ confidence interval and the bias corrected and accelerated results are seen in Table 2. As can be seen in Table 2, the indirect effect of the need for social approval through social anxiety on happiness (i.e. the difference between the total and direct effect $/ \mathrm{c}-\mathrm{c}^{\prime}$ ) is statistically significant (point estimate $=-.4273$ and $95 \%$ BCa GA $[-.5923,-.2766])$. The indirect effect of the social avoidance sub-dimension (point estimate $=-.2597$ and $95 \%$ BCa GA $[-.4133,-.1189])$, the fear of being criticized sub-dimension (point estimate $=.2239$ and $95 \%$ BCa GA [.0083, .4342], the sense of worthlessness sub-dimension (point estimate= -.3914 and $95 \%$ BCa GA $[-.5693,-.2421]$ ) of social anxiety mediating between the need for social approval and happiness is significant. The mediation role of the sub-dimension of being criticized is significant, yet contrary to the others, in the opposite direction (negative). As can be seen in Table 1, like the other sub-dimensions of social anxiety, the sub-dimension of being criticized is in a negative correlation with happiness. However, it has a positive view in the mediation model. This can be explained by the existence of suppressor variable or variables $[52,53]$. As the other variables in the model are stronger, the effect of the sub-dimension of being criticized on the total effect is relatively smaller. That is, its effect on the total effect in the model is smaller than it would be due to the other two variables. Suppression occurs when the indirect effect has a sign opposite to that of the total effect. This seems to have happened in the model in the current study. Thus, when the suppressor variable is excluded from the study, its effect on the total effect will be very small or insignificant. In this analysis, when the point estimate of the indirect effect is examined, it is seen that the total indirect effect is -.4273. As the direction of the sub-dimension of being criticized is opposite, when the indirect effects of the sub-dimensions are summed, it is seen that almost the same indirect effect occurs $([-.2597]+$ $[.2239]+[-.3914]=-4272)$. 
Table 2. Comparison of the indirect and specific indirect effects of the need for social approval through social anxiety on happiness

\begin{tabular}{|ccccccc|}
\hline & & Product of coefficients & & \multicolumn{2}{c|}{$\begin{array}{c}\text { Bootstrapping } \\
\text { 95\% BCa Confidence Interval }\end{array}$} \\
\hline Effects & Point & SH & $\mathrm{z}$ & $p$ & Low & High \\
\hline Estimate & -.4273 & .0815 & & & -.5923 & -.2766 \\
Sotal Indirect Effect & -.2597 & .0735 & -3.5327 & .0004 & -.4133 & -.1189 \\
Fear of Being Criticized & .2239 & .0997 & 2.2911 & .0220 & .0083 & .4342 \\
Sense of Worthlessness & -.3914 & .0780 & -5.0158 & .0000 & -.5693 & -.2421 \\
Comparisons & & & & & & -.1937 \\
C1-Social avoidance-Being criticized & -.4836 & .1488 & -3.5337 & & -.7811 & .3830 \\
C2-Social avoidance-Worthlessness & .1317 & .1246 & 2.2911 & & -.1087 & .9543 \\
C3-Being criticized-Worthlessness & .6152 & .1688 & -5.0158 & & .2906 & \\
\hline
\end{tabular}

$\mathrm{N}=285, \mathrm{k}=5000,{ }^{*} p<.05,{ }^{* *} p<.01, \mathrm{BCa}$ : Bias corrected and accelerated 5000 bootstrap sample

In addition to these, when the paired comparisons related to the effect of the mediator variables are examined, it is seen that while the sub-dimensions of social avoidance $(\mathrm{C} 1 ; 95 \% \mathrm{BCa}$ GA $[-.7811,-.1937])$ and sense of worthlessness (C3; 95\% BCa GA [.2906, .9543]) are stronger mediators than the sub-dimension of being criticized, the sub-dimensions of social avoidance and sense of worthlessness are not different from each other in terms of their mediation effect on the basis of their point estimate zero interval content according to $95 \% \mathrm{BCa}$ confidence intervals (C2; 95\% BCa GA $[-.1087, .3830])$.

\section{Discussion, Results and Suggestions}

In the current study, it was found that the total effect of the need for social approval is significant. Moreover, the direct effect of the need for social approval on the social avoidance, the fear of being criticized and the sense of worthlessness sub-dimensions of social anxiety being the mediator variable was found to be significant. The effect of the social avoidance, the fear of being criticized and the sense of worthlessness sub-dimension of the mediator variable of social anxiety on happiness is significant. When the need for social approval and the sub-dimensions of the mediator variable of social anxiety (social avoidance, fear of being criticized and sense of worthlessness) were simultaneously included in the equation, the relationship between the need for social approval and happiness decreased in terms of direct effect; yet, the significance level remained the same. Thus, it can be argued that social anxiety plays a mediation role between the need for social approval and happiness. When the paired comparisons regarding the strength of mediator variables were examined, it was found that the sub-dimensions of social avoidance and sense of worthlessness are stronger mediators than the sub-dimension of being criticized. Moreover, it is seen that the whole model is significant and explains $27 \%$ of the total variance of happiness.

These findings show that with increasing need of social approval, social anxiety also increases but happiness decreases. It is seen that research focusing on the relationship between the need for social approval and happiness is limited. In a correlational study by Karaşar and Ögülmüş [2], it was found that the need for social approval and happiness are significantly and negatively correlated.

When the need for social approval increases, individuals' fear of being judged negatively also increases and they prefer to withdraw themselves from social environments. These people are hypersensitive to rejection and focus on others' opinions. They are very afraid of being negatively judged by others in social settings [41]. Such people are always deep in such thoughts as "What are other people thinking; what should I tell or do to be approved by others?" in their social interactions and they can get engaged in negative feelings when they are not approved. At the same time, when people get more focused on what others are thinking, their level of anxiety may increase in social environments. The increasing social anxiety can make the person feel bad. Anxiety experienced in social environments makes social interactions more difficult, decreasing the individual's self-esteem, making him/her lonely and increasing negative feelings.

Chiba, Iketani, Han and Ono [43] noted that the individuals with high need for social approval take great care to leave positive impressions; thus, they are more prone to experiencing social anxiety. Leary and Kowalski [44] pointed out that the individuals with high need for social approval experience more social anxiety than the individuals with low need for social approval. People having social anxiety disorder can be confronted with one or more psychological disorders in their lives [34]. In literature there are some studies supporting the findings of the current study. There are various studies reporting a negative correlation between social anxiety and psychological well-being [37,38]. In a study conducted by Demir and Kutlu [39] on university students, it was found that social interaction anxiety negatively predicts happiness. They found that with increasing level of social interaction anxiety, happiness decreases. The reflection of the presence or absence of social relationships as a basic 
human need on the individual has been investigated in different ways. Being successful in social relations; that is, establishing effective and appropriate social relations, is also seen as an important source of happiness. Diener and Seligman [29] emphasized the importance of social bonds for happiness. Therefore, individuals who are experiencing social anxiety are unhappy because they can't meet their social needs and perhaps they experience negative feelings of anxiety.

In the literature, there is no study exploring the mediation role of social anxiety in the relationship between the need for social approval and happiness. Furthermore, the research focusing on the relationships between the need for social approval, social anxiety and happiness is quite limited. Therefore, discussion of the research findings in relation to the literature remains restricted, which can be a limitation of the current study. Further research may focus on different study groups. In the current study, the mediation role of social anxiety in the relationship between the need for social approval and happiness was investigated; further research can look at the mediation role of different variables. Particularly in cases where the need for social approval or social anxiety is intense, individuals can get lonely or their happiness may lower as their self-esteem drops. Therefore, a mediation model including loneliness and self-esteem as well can be tested. The individuals with high need for social approval my say what others want to hear rather than what they really think so as to be approved and accepted by others. That is, the individuals with high need for social approval may not be themselves. And since they cannot express their thoughts and emotions as they are, they suppress them, which can make them unhappy. Thus, the mediation role of being oneself in the relationship between the need for social approval and happiness can be explored. More specifically, the mediation role of being oneself in the relationship between the need for social approval and negative feelings can be investigated.

Given the study group of the current research is comprised of university students and that they are in their adolescence period, social relationships become more important. As the natural requirements of this period, they strive to be academically successful, they engage in job interviews and they can make efforts to find their partners. As indicated by the findings of the current research, social anxiety and need for social approval stand as obstacles to happiness. Thus, offering different opportunities for students to be involved in different extracurricular activities and creating environments for them to engage in social interactions seem to be important. It can also be suggested that group psychological counseling, psycho-educational activities and group activities should be conducted with students. Moreover, as a source of negative feelings and low satisfaction in life, the need for social approval can be addressed through individual psychological counseling activities.

\section{REFERENCES}

[1] Özbay, Y. \& Palanc1, M. (2001). Sosyal kayg1 ölçeği: geçerlik ve güvenirlik çalışması. VI. Ulusal Psikolojik Danışma ve Rehberlik Kongresi, ODTÜ, Ankara, Türkiye.

[2] Karaşar, B., \& Öğ̈̈lmüş, S. (2016). Sosyal onay ihtiyacının çeșitli değişkenler açısından incelenmesi. Uludağ Üniversitesi Ĕgitim Fakültesi Dergisi, 29 (2), 469-495.

[3] Doğan, T. \& Sapmaz, F. (2012). Oxford mutluluk ölçeği türkçe formunun psikometrik özelliklerinin üniversite öğrencilerinde incelenmesi. Düşünen Adam: Psikiyatri ve Nörolojik Bilimler Dergisi, 25(4), 297-304.

[4] Hayes, A. F. (2012). PROCESS: A versatile computational tool for observed variable mediation, moderation, and conditional process modeling. It was obtained from the http://www.afhayes.com/public/process2012.pdf website on February 24, 2013.

[5] Hayes, A. F. (2013). Introduction to Mediation, Moderation, and Conditional Process Analysis: A Regression-Based Approach. New York: Guilford Press.

[6] Frey, B. S. \& Stutzer, A. (2002). What can economists learn from happiness research? Journal of Economic Literature. Vol XL. (June 2002), 402-435.

[7] Lyons, M. D., Huebner, E. S., Hills, K. J., \& Shinkareva, S. V. (2012). The dual-factor model of mental health further study of the determinants of group differences. Canadian Journal of School Psychology, 27 (2), 183-196.

[8] Diener, E. (1984). Subjective well-being. Psychological Bulletin, 95 (3), 542-575.

[9] Myers, D. G., \& Diener, E. (1995). Who is happy?. Psychological Science, 6 (1), 10-19.

[10] Lent, R. W. (2004). Toward a unifying theoretical and practical perspective on well-being and psychosocial adjustment. Journal of Counseling Psychology, 51 (4), 482-509.

[11] Ryff, C. D. (1989). Happiness is everything, or is it? Explorations on the meaning of psychological well-being. Journal of Personality and Social Psychology, 57 (6), 1069-1081.

[12] Tennant, R., Hiller, L., Fishwick, R., Platt, S., Joseph, S., Weich, S., Parkinson, J., Secker, J., \& Stewart-Brown, S. (2007). The Warwick-Edinburgh mental well-being scale (WEMWBS): Development and UK validation. Health and Quality of Life Outcomes, 5 (1), 50-63.

[13] Deci, E. L., \& Ryan, R. M. (2000). The "what" and "why" of goal pursuits: Human needs and the self-determination of behavior. Psychological Inquiry, 11, 227-268.

[14] İlhan, T. (2009). Üniversite öğrencilerinin benlik uуuти modeli: Yaşam amaçlari, temel psikolojik ihtiyaçlar ve öznel iyi oluş. Doktora Tezi, Gazi Üniversitesi Eğitim Bilimleri Enstitüsü, Ankara.

[15] Witter, R. A., Stock, W. A., Okun, M. A., \& Haring, M. J. (1985). Religion and subjective well-being in adulthood: A 
quantitative synthesis. Review of Religious Research, 26 (4), 332-342.

[16] Francis, L. J., Ok, U., \& Robbins, M. (2017). Mystical orientation and psychological health: A study among university students in Turkey. Mental Health, Religion \& Culture, 20 (4), 405-412.

[17] Sanchez-Alvarez, N., Extremera, N., \& Fernandez-Berrocal, P. (2016). The relation between emotional intelligence and subjective well-being: A meta-analytic investigation. The Journal of Positive Psychology, 11 (3), 276-285.

[18] Yang, X. (2016). Self-compassion, relationship harmony, versus self-enhancement: Different ways of relating to well-being in Hong Kong Chinese, Personality and Individual Differences, 89, 24-27.

[19] Zessin, U., Dickhauser, O., \& Garbade, S. (2015). The relationship between self-compassion and well-being: A meta-analysis. Applied Psychology: Health and Well-Being 7 (3), 340-364.

[20] Brdar, I., \& Kashdan, T. B. (2010). Character strengths and well-being in Croatia: An empirical investigation of structure and correlates. Journal of Research in Personality, $44,151-154$.

[21] Cenkseven Önder, F., \& Mukba, G. ( 2017). Üniversite ögrencilerinde umut ve psikolojik iyi oluş arasındaki ilişkide yaşam amacının arac1 rolü. The Journal of Academic Social Science Studies, 62, 103-116.

[22] Mak, W. W. S., Ng, I. S. W., \& Wong, C. C. Y. (2011). Resilience: Enhancing well-being through the positive cognitive triad. Journal of Counseling Psychology, 58 (4), 610-617.

[23] Gürgân, U. (2014). Üniversite öğrencilerinin yılmazlık ve iyilik halinin bazı değişkenlere göre incelenmesi. NWSA-Education Sciences, 9 (1), 18-35.

[24] Baytemir, K. (2016). The mediation of interpersonal competence in the relationship between parent and peer attachment and subjective well-being in adolescence. Education and Science, 41 (186), 69-91.

[25] Segrin, C., \& Taylor, M. (2007). Positive interpersonal relationships mediate the association between social skills and psychological well-being. Personality and Individual Differences, 43 (4), 637-646.

[26] Argyle, M. \& Lu, L. (1990). Happiness and social skills. Personality and Individual Differences, 11 (12), 1255-1261.

[27] Cheng, H. \& Furnham, A. (2002). Personality, peer relations, and self-confidence as predictors of happiness and loneliness. Journal of Adolescence, 25 (3), 327-339.

[28] Demir, M., Jaafar, B., Bilyk, N., \& Ariff, M.R.M. (2012). Social skills, friendship and happiness: a cross-cultural investigation. The Journal of Social Psychology, 152 (3), 379-385.

[29] Diener, E. \& Seligman, M. E. (2002). Very happy people. Psychological Science, 13 (1), 81-84.

[30] Myers, D. (2000). The funds, friends, and faith of happy people. American Psychologist, 55 (1), 56-67.
[31] Bacanlı, H. (1999). Sosyal beceri eğitimi. Ankara: Nobel Yayın Dağıtım.

[32] Aronson, E., Wilson, T. D. \& Akert, R. M. (2012). Sosyal psikoloji. (O. Gündüz, Çev.). İstanbul: Kaknüs Yayınları.

[33] Kring, A. M., Johnson, S. L., Davison, G., \& Neale, J. (2017). Anormal psikoloji. (Çeviri Edt. Muzaffer Şahin). Nobel Akademik Yayıncılık: Ankara.

[34] Antony, M. M. \& Rowa, K. (2008). Social anxiety disorder. Advances in psychotherapy. Evidence-based practice. Hogrefe Publishing.

[35] Hollander, E. \& Bakalar, N. (2005). Coping with social anxiety. Henry Holt \& Co, New York.

[36] Sushma, B., Padmaja, G. \& Agarwal, S. (2016). Well-being, psychosocial problems and social interaction anxiety in children. The International Journal of Indian Psychology, 3 (4), 30-43.

[37] Chianeh, J. \& Kasraie, S. (2016). Academic self-efficacy and social anxiety with psychological wellbeing of high school students. Modern Journal Of Language Teaching Methods (MJLTM), 6 (4.1), 215-221.

[38] Khosroshahi, J.B. \& Abad, T.H.N. (2012). The relationship between social anxiety, optimism and self-efficacy with psychological well-being in students. J Urmia Univ Med Sci, 23 (2), 115-122.

[39] Demir, Y. \& Kutlu, M. (2016). Üniversite öğrencilerinde sosyal etkileşim kaygısı ile mutluluk arasındaki ilişki: yalnızlığın aracı rolü. GEFAD / GUJGEF, 36 (1), 195-210.

[40] Fehr, E. \& Falk, A. (2001). Psychological foundations of incentives. Institute for Empirical Research in Economics University of Zurich Working Paper Series. Working Paper No. 95, Paper presented at the Annual Conference of the European Economic Association.

[41] Dilbaz, N. (2000). Sosyal anksiyete bozukluğu: tanı, epidemiyoloji, etiyoloji, klinik ve ayırıcı tanı. Klinik Psikiyatri Dergisi, 3 (2), 3-21.

[42] Türkçapar, H. (1999). Sosyal fobinin psikolojik kuramı. Klinik Psikiyatri, 2, 247-253.

[43] Chiba, T., Iketani, S., Han, K., \& Ono, A. (2009). A comprehensive model of anxiety in gift giving. International Review of Business Research Papers, 5(4), 322-334.

[44] Leary, M. R. \& Kowalski, R. M. (1995). Social anxiety. New York: Guilford.

[45] Karaşar, B. (2014). Sosyal onay ihtiyacinin çeşitli değișkenler açısından incelenmesi. Doktora Tezi. Ankara Üniversitesi Eğitim Bilimleri Enstitüsü. Ankara.

[46] Baumeister, R. F. \& Leary, M. R. (1995). The need to belong: Desire for interpersonal attachment as a fundamental human motivation. Psychological Bulletin, $117,497-529$.

[47] İzgiç, S., Akyüz, G., Doğan, O., \& Kuğu N. (2000). Üniversite öğrencilerinde sosyal fobi yaygınlığı. Anadolu Psikiyatri Dergisi, 1, 207-214.

[48] Tekin, M. (2008). Üniversite öğrencilerinde bilissel model çerçevesinde sosyal anksiyete bozukluğu ve alkol kötüye 
kullanımı ilişkisi. Yüksek Lisans Tezi. Muğla Üniversitesi, Muğla.

[49] Gültekin B.K, \& Dereboy İ. F. (2011). The prevalence of social phobia, and its impact on quality of life, academic achievement, and identity formation in university students. Türk Psikiyatri Dergisi. Fall: 22 (3), 150-158.

[50] Fraenkel, J. R., Wallen, N. E. \& Hyun, H. H. (2012). How to design and evaluate research in education (8th ed.). New York: McGraw Hill.

[51] Hills, P. \& Argyle, M. (2002). The oxford happiness questionnaire: a compact scale for the measurement of psychological well-being. Personality and Individual Differences, 33, 1073-1082.

[52] MacKinnon, D.P., Krull, J.L. \& Lockwood, C.M. (2000). Equivalence of the mediation, confounding and suppression effect. Prevention Science 1(4), 173-81.

[53] Rucker, D.D., Preacher, K.J., Tormala, Z.L. \& Petty, R. E. (2011). Mediation Analysis in Social Psychology: Current Practices and New Recommendations. Social and Personality Psychology Compass, 5(6), 359-371.

\footnotetext{
* This study was presented in abstract form at the international Academic Research Congress, 18-21 October, 2017 in Alanya / Turkey. Also the current study was supported by the BAP unit of Amasya University.
} 